\title{
ON UNBOUNDED OSCILLATION OF FOURTH ORDER FUNCTIONAL DIFFERENCE EQUATIONS
}

\author{
A. K. TRIPATHY
}

Abstract. In this work, an illustrative discussion have been made on unbounded oscillation properties of a class of fourth order neutral functional difference equations of the form:

$$
\Delta^{2}\left(r(n) \Delta^{2}(y(n)+p(n) y(n-\tau))\right)+g(n) G(y(n-\sigma))-h(n) H(y(n-\alpha))=0
$$

under the assumptions

$$
\sum_{n=0}^{\infty} \frac{n}{r(n)}=\infty, \quad \sum_{n=0}^{\infty} \frac{n}{r(n)}<\infty .
$$

New oscillation criteria have been established for different ranges of $p(n)$ with $|p(n)|<\infty$.

Mathematics subject classification (2010): 39A10, 39A12.

Keywords and phrases: Oscillation, non-oscillation, fourth order nonlinear, delay, neutral, functional difference equation, discrete Taylor's formula.

\section{REFERENCES}

[1] R. P. Agarwal, Difference Equations and Inequalities, Marcel Dekker, New York, 2000.

[2] R. P. Agarwal, M. Bohner, S. R. Grace and D. O'Regan, Discrete Oscillation Theory, Hindawi Publishing Corporation, New York, 2005.

[3] R. P. AgarwaL, S. R. GRACE AND P. J. Y. WONG, Oscillation of fourth order nonlinear difference equations, Int. J. Difference Equ., 2 (2007), 123-137.

[4] M. Bohner And A. Peterson, Dynamic Equations on Time Scales: An Introduction with Applications, Birkhaüser, Boston, 2001.

[5] M. Bohner And A. Peterson, Advances in Dynamic Equations on Time Scales, Birkhaüser, Boston, 2003.

[6] G. E. Chatzarakis And G. N. Miliaras, Asymptotic behaviour in neutral difference equations with negative coefficients, Math. Slovaca, 64 (2014), 391-402.

[7] J. R. GRAEF AND E. ThANDAPANI, Oscillatory and asymptotic behaviour of fourth order nonlinear delay difference equations, Fasci. Math., 31 (2001), 23-36.

[8] J. R. GRAEF, S. PANIGRAhi AND P. R. RedDy, On oscillatory and asymptotic behaviour of fourth order nonlinear neutral delay dynamic equations with positive and negative coefficients, Math. Slovaca, 64 (2014), 347-366.

[9] M. MigDA, Asymptotic properties of nonoscillatory solutions of higher order neutral difference equations, Opuscula Math., 26 (2006), 507-514.

[10] M. Migda AND J. Migda, Oscillatory and asymptotic proporties of solutions of even order neutral difference equations, J. Difference Equ. Appl., 15 (2009), 1077-1084.

[11] S. PANIGRAHI, J. R. GRAEF AND P. R. REDDY, Oscillation results for fourth order nonlinear neutral dynamic equations, Commun. Math. Anal., 15 (2013), 11-28.

[12] N. PARHI AND A. K. TRIPATHY, Oscillation of a class of nonlinear neutral difference equations of higher order, J. Math. Anal. Appl., 284 (2003), 756-774.

[13] R. N. RATH, B. L. BARIK AND S. K. RATH, Oscillation of higher order neutral functional difference equations with positive and negative coefficients, Math. Slovaca, 60 (2010), 361-384. 
[14] E. Thandapani, P. Sundaram, J. R. Graef, A. Miciano and P. Spikes, Classification of nonoscillatory solutions of higher order neutral type difference equations, Arch. Math.(Brno), 31 (1995), 263-277.

[15] E. Thandapani AND I. M. ARockias Amy, Oscillatory and asymptotic behaviour of fourth order nonlinear neutral delay difference equations, Indian J. Pure and Appl. Math., 32 (2001), 109-123.

[16] A. K. TRIPATHY, Oscillation of fourth-order nonlinear neutral difference equations-I, Math. Slovaca, 58 (2008), 221-240.

[17] A. K. TRIPATHY, Oscillation of fourth-order nonlinear neutral difference equations-II, Math. Slovaca, 58 (2008), 581-604.

[18] A. K. TRIPATHY, New oscillation criteria for fourth-order nonlinear neutral difference equations, Adv. Dyn. Appl., 8 (2013), 387-399.

[19] A. K. TRIPATHY, On oscillatory nonlinear fourth order difference equations with delays, Math. Bohem., 143 (2018), 25-40. 